\title{
ASSESSMENT OF THE ROLE OF SCHOOL COMMUNITY RELATIONSHIP IN THE DEVELOPMENT OF SECONDARY EDUCATION IN ZAMFARA STATE
}

\author{
BAKWAI, BALA
}

\begin{abstract}
This study investigated the roles of school community relationship in the development of secondan education in Zanfara State. The population of the study consisted of all the principals, vice principals, teachers and PTA officials of the 89 senior secondary schools in Zamfara state. The research design adopted was descriptive suney and questionnaire was used in collecting data. Among the major findings of the study is that school commumity relationship is very significant in the development secondary education in Zamfara State because it helps in the discipline of students, welfare of teachers, the planming of curriculum, information sharing and dissemination, provision of school facilities, finance, policies, security. management decision and in 'monitoring students' progress. It is also found resources which Zamfara State Senior Secondary Schools required for encouraging school community relationship are classrooms, halls and lecture theatres, playgrounds, libraries, business centres, restaurants and/or canteens, furniture, parks and gardens and school farms. It is concluded that school community relationship plays very significant role in the development of secondary education in Zamfara State. It is recommended that School principals should have some information about the composition of the community, what community opinion is regarding both broad educational issues and day to day operation of the school itself. And also school administrators should acquaint themselves with educational resources available in the community in order that they can be utilized to enrich and enhance the school programmes.
\end{abstract}

\section{Introduction}

School as an open system and a social organization thrives on the effective interrelationship within it and with its relevant communities. What happens in a school affects the community, and what happens in the community affects school (Nwankwo, Nwokafor, Ogunsanwo \& Ighalo, 1985). This means that community builds its schools and the schools build their communities (Sidhu, 2007). Therefore, school community interdependence is unbreakable. There is a reciprocal relationship. The two works for one another and the two have direct impact on one another. If schools are expected to be successful in their primary mission of educating the community's children, they need to know a great deal about the community and the families from which the children come. This means that a school cannot exist in isolation but in cooperation with the community in which it finds itself (Ihebereme, 2008).

The processes of social interaction are the bases for creating social relationship. According to Calhoun, Light and Keller (1998) social relationships are relatively enduring patterns of interaction between two or more people. Most people have many social relationships, from casual acquaintance to intimate friendships and close family bond. School community relationship is a two-way symbiotic arrangement through which the school and the community co-operate with each other for the realization of goals of the community and vice versa. It is the degree of understanding and goodwill, 
which exists between the school and the community (Okorie, Ememe \& Egu 2009). School as a training centre helps develop pupils into efficient social beings and to train them to further educate and uplift members of the society. The students are prepared to launch a vigorous and systematic crusade against social evils, anti - social habits and unhygienic habit. School interacts with people of the community and is linked with the larger society. The school is a special envirenment where a certain quality of life types of activities and occupations are provided with the object of securing child's development along desirable lines (Mishra, 2007).

The function of the traditional school was to transmit the social heritage of the community. Its role was too academic in nature. The modern sociological view of education lay down that the school constantly draws upon social life and activities for its subject matter, its methods of teaching and its methods of work. There must be a conscious and continuous intercourse, a free give and take between the little world of the school and bigger one outside. The school has to arrange for the students opportunities to participate in social services, health campaigns, development plans, and other public activities. Any divorce between school and community is likely to make teaching artificial. School is a place where both children and adult are educated for progress of the whole community. School buildings, furniture, equipment, human resources, etc. are public property. They should be unhesitatingly placed at the disposal of the community after school hours. School teachers should also come forward and place their knowledge and experience at the disposal of community and assume the role of guides and leaders of the social group. The school library and play grounds can especially be of significant service to the community (Ihebereme, 2008).

The school also helps arrange public lectures, exhibitions, fairs, tournaments, symposia, discussions, recreational programmes and other social functions that involve the community as a whole. The programme of adult education can also be co-ordinate with the school. The school grounds may be thrown open to the other children of the locality who have no other place for playing. The school will serve as a society in miniature-a small but ideal community. It will be a model for the society around. It will be the peoples' school, but at the same time it will give new direction to the people and community. It will act as a watch dog against social degeneration. By enhancing its own status and contribution it will enhance the status of the community as a whole (Sidhu, 2007).

The increase in single-parent and dual income families... coupled with the gradual disappearance of village-like communities... leaves a growing number of children and families woefully isolated from helping relationships, peer and emotional support, and access to referral services (Fiore, 2006). According to him, "When families, schools and community institutions (e.g. local business, community colleges and health agencies) collectively agree upon their goals and decide how to reach them, everyone benefits." He identifies the following as the importance of school community relationship:

1. Schools enjoy the informed support of families and community members. 
2. Communities can provide schools with a context and environment that can either complement and reinforce the values, culture, and learning the school provide for their students or negates everything the school strive to accomplish.

3. Communities can furnish schools with crucial financial support system as well as the social and cultural values necessary for success and survival in contemporary society.

4. Communities have the potential to extend a variety of opportunities to students and to their families-social, cultural and vocational.

5. Schools, in turn, offer communities a focal point of educational services for children. By working together, schools, families, and communities can prepare for a more promising future.

Okorie, Ememe and Egu (2009) of the Department of Educational Management Faculty of Education, University of PortHarcourt, conducted a research on school-community relations in the development of secondary schools with the focus on Aba Educational Zone of the state. The data was collected with the use of 10-item modified 4-points Likert. instrument from a sample of 472 teachers and principals which total population were 1888. The data was collected. The purpose of the study was to determine the role of the community in ensuring the academic performance of students in secondary schools in Aba Zone, and to determine the role of the community in the provision of facilities in the school in Aba Zone. The general high means recorded in their study indicated that communities play important roles ensuring the academic performance of students and provision of facilities in schools. In support of this, Koko and Nwiyi (2006) stressed that communities should be able to execute programmes that will provide resources, manpower and funds to the schools. In keeping with finding of this study, Kenkwo (1992) advised that communities should work hard and together to provide educational programmes such as counseling and scholarship for the youths. Collaborating further, Agabi, Okorosaye-Orubite, Ezekiel-hart and Egbezor (2005) outlined very important areas where community had identified itself in the development of the school to include: Donation of land for building the school and funding and accommodations to teachers. These researchers concluded that communities play active roles in ensuring the academic performance and the provision of amenities in schools. Communities involvement in the development of schools in Aba Educational Zone has been very visible and hopes to achieve the aim of elevating the status of secondary education in the Zone. They recommend that. Communities should be made to be more actively involved in other areas of school activities, like enforcement of discipline, and that members of the community should be more committed to the affairs of the school and show same by constantly monitoring the academic activities in the school.

The above research is relevant to a research like this because it is conducted at a secondary school level and is concerned with school-community relations. Both researches aimed at developing strategies of managing school-community relations for the development of secondary school. The different between the two studies is the 
area of study. School-community relations are well developed in Aba Education Zone as indicated by the findings of Okorie, Ememe and Egu (2009). Thus the conclusion cannot be generalized to Zamafara State where school-community relation is believed to be below that of Aba in Southern part of Nigeria. Despite the difference in time frames, educational advancement, geographical environment and sociocultural variation. the extent to which this research could benefit this study should not be underestimated. The above study will definitely be of values to this current study.

\section{Theoretical Framework of the Study}

The theory which is deemed most relevant in the study of relationships between school and community is Chester Barnard Co-operative theory. This theory defines organization as a system of co-operation whereby people work together for a common goal. And school cannot succeed without the cooperation of several individuals within the community. School community relationship tries to create mutual cooperation between school and community. It brings people and school together. School community relationship therefore is co-operative in nature and is man oriented. Barnard's co-operative theory is essentially man oriented (Oyedeji, 1998:19). Barnard is of the opinion that a person can and will be willing to accept a command as authoritative only if the following four conditions hold.

a) The person can execute and is able to understand the communication.

b) At the time of making decision it should be believed that it is not inconsistent with the aim of the organisation.

c) The person believes that these goals are compatible with his personal interest.

d) The person is able to mentally and physically comply with the communication.

Although this is deemed relevant, there are gaps which exist between Chester Barnard's theory and practice. In Zamfara State, there seems to be lack of effective communication between schools and communities. This lack of effective communication brings about lack of understanding between schools and communities which consequently leads to lower degree of co-operation between them. This trend may occur as a result of school administrators ignoring the role of school community relationship in the development of schools. Hence, this study intends to investigate the significant role of school community relationship in the development of secondary education in Zamfara State.

\section{Statement of the problem}

Increase in the demand of education has led to the establishment of many schools and expansion of the existing ones. This trend has grown to an extent that government in Nigeria has been unable to single-handedly provide qualitative education to all those who demand it due to financial implications. According to Madiewesi (1991) government has to invite the people to participate actively in running secondary schools especially in the area of providing supporting educational services. Also according to Musaazi (1994) the sudden and continuous increase in secondary school 
population has led to the inadequacy of facilities and equioment in many Nigerian schools. This is because for goals and objectives of the school systems to be achieved, funds and facilities are required for executing various activities or schools programmes.

But the community members which government invite seems not to acknowledge the invitation. This is because a visit to any secondary schools in Zamfara State would reveal how members of communities generally fold their arms waiting for government to maintain the tradition of construction and maintenance of physical structures, the supply of stationeries and meeting the current expenditure needed for secondary education. This is an issue of concern because it is only through the help of community that secondary schools in Zamfara state could hold any future. Consequently, this study investigated the roles of school community relationship in the development of secondary education in Zamfara State.

\section{Objectives of the Study}

This is designed to achieve the following objectives:

1. To identify the significances of school community relationship in the development of Secondary education in Zamfara State.

2. To identify school resources that can be used to encourage school community relationship in Senior Secondary Schools in Zamfara State.

\section{Research Questions}

The following questions are set as a guide for this research:

1. What is the significance of school community relationship in development of Secondary education in Zamfara State?

2. What are the school resources that can be used to encourage school community relationship in Senior Secondary Schools in Zamfara State?

\section{Research Design}

This study used descriptive survey approach where portion of the entire population was subjected to analysis and the findings was used to draw conclusion on the entire population.

\section{Population and Sample}

The population of this study comprised of all the 89 principals, 178 viceprincipals, 3158 teachers and 818 PTA officials of all public senior secondary schools in Zamfara state. Convenient sampling technique was used to select 16 senior secondary schools. Taking into cognizance some different characteristics among the senior secondary schools such as day and boarding; urban and rural; single sex and mixed; and science, technical and commercial schools, the researcher used stratified random sampling to select the 16 schools. Whereas Krejcie and Morgan (1971) table for determining sample size from a given population was used to determine the required sample size for teachers. A sample size of 341 teachers was determined. Furthermore, proportionate random sampling of $49 \%$ was used to select the 341 teachers from 
the selected Senior Secondary Schools. This was because, 341 was $49 \%$ of total number of teachers in the selected schools which was 699 . The total sample is therefore made up of 16 principals, 32 vice principals. 64 PTA officials and 341 teachers

\section{Research Instrument}

The instrument used for this research was self-designed questionnaire based on 2-point scale titled 'SchoolCommunity Relationship in Developing Secondary Education Questionnaire (SCRDSEQ). It consisted mainly of close-ended structures which required the respondents to tick their best option and was structured on Two Point Scale i.e. $A=$ Agreed and $D=$ Disagreed.

\section{Validity and Reliability of the Instrument}

The questionnaire designed for this research was validated by different experts in the field of Educational Research and Educational Management in the Faculty of Education and Extension Services, Usmanu Danfodiyo University, Sokoto. The questionnaire was validated for its relevance to subject matter, appropriateness of the text content and coverage of the content area. After making all the necessary adjustments, the experts approved the instrument as being valid for collecting data in this study.

In order to determine the reliability of the questionnaire, a pilot study was conducted using test- retest method of reliability with an interval of three weeks in order to establish the stability of the questionnaire over time .Using Pearson Product Moment Correlation Coefficient formula, reliability co-efficient of 0.82 was obtained.

\section{Method of Data Collection}

The researcher personally visited all the selected senior secondary schools in the company of trained research assistants during the period of data collection. This facilitate on the spot collection of the completed instrument. A total of 453 copies of the questionnaire were produced and distributed but only 398 copies of the questionnaire were retrieved and subjected to analysis. The 18 unfilled copies were considered as mortality loss.

\section{Method of Data Analysis}

In order to analyse the data collected, techniques of descriptive statistics were used. These techniques include frequency count, simple percentages and tables.

\section{Data Presentation and Analysis}

Q1: What is the significance of school community relationship in developing Secondary Education in Zamfara State?

This research question was answered and presented in table 1. 
Table 1: Significance School Community Relationship in the Development of Secondary Education in Zamfara State.

\begin{tabular}{llllll}
\hline \multirow{2}{*}{ S/N } & Item & Agreed & \multicolumn{2}{c}{ Disagreed } \\
& & Freq. & $\%$ & Freq. & $\%$ \\
\hline 1. & It helps in the discipline of students & 378 & $95 \%$ & 20 & $5 \%$ \\
2. & It helps in the welfare of teachers. & 286 & $72 \%$ & 112 & $28 \%$ \\
3. & It helps in the planning effective curriculum & 287 & $72 \%$ & 111 & $28 \%$ \\
4. & It helps in monitoring student progress & 318 & $80 \%$ & 80 & $20 \%$ \\
5. & It helps in information sharing and dissemination & 319 & $80 \%$ & 79 & $20 \%$ \\
6. & It helps in making effective management decision & 330 & $83 \%$ & 68 & $17 \%$ \\
7. & It helps in the provision of security to the school & 326 & $82 \%$ & 72 & $18 \%$ \\
\hline
\end{tabular}

From table 1 , it is obvious that school community relationship is very important among secondary schools in Zamfara State. Item 1 shows that $95 \%$ of the participants agreed that school community relationship helps in the discipline of students. In item 2 , it is indicated that $72 \%$ of the participants agreed that school community relationship helps in the welfare of teachers. In item 3, it is indicated that $72 \%$ of the participants agreed that school community relationship helps in the provision of school facilities.

In item 4, it is shown that $80 \%$ of the participants agreed that school community relationship helps in the provision fund for financing school projects. In item 5 , it is indicated that
$80 \%$ of the participants agreed that school community relationship helps in the provision of health services. Item 6 indicates that $83 \%$ of the participants agreed that school community relationship helps in the provision of security to schools. Item 7 indicates that $82 \%$ of the participants agreed that school community relationship helps in the provision of security to schools.

Q2: What are the types of school resources are used to encourage school community relationship in Senior Secondary Schools in Zamfara State?

This research question was answered and presented in table 2 .

Table 2: Type of School Resources Used to Encourage School Community Relationship in Senior Secondary Schools in Zamfara State.

\begin{tabular}{|c|c|c|c|c|c|}
\hline \multirow{2}{*}{$\mathbf{S} / \mathbf{N}$} & \multirow{2}{*}{ Item } & \multicolumn{2}{|l|}{ Agreed } & \multicolumn{2}{|c|}{ Disagreed } \\
\hline & & Freq. & $\%$ & Freq. & $\%$ \\
\hline 1. & $\begin{array}{l}\text { Classrooms can be used by the community when } \\
\text { school close or is on holiday. }\end{array}$ & 292 & $73 \%$ & 106 & $27 \%$ \\
\hline 2. & School library can provide books for parent to use. & 214 & $54 \%$ & 184 & $36 \%$ \\
\hline 3. & $\begin{array}{l}\text { School halls can be used by the community for social } \\
\text { events. }\end{array}$ & 275 & $69 \%$ & 123 & $31 \%$ \\
\hline 4. & $\begin{array}{l}\text { School play grounds can be used by the community } \\
\text { for local games. }\end{array}$ & 268 & $67 \%$ & 130 & $33 \%$ \\
\hline 5. & $\begin{array}{l}\text { School parks can be used by community during } \\
\text { festive seasons. }\end{array}$ & 250 & $63 \%$ & 148 & $37 \%$ \\
\hline
\end{tabular}




\begin{tabular}{llllll}
\hline 6. & $\begin{array}{l}\text { School business centres can provide services to the } \\
\text { community. }\end{array}$ & 322 & $81 \%$ & 76 & $19 \%$ \\
7. & $\begin{array}{l}\text { School technical workshop can be used for community } \\
\text { services }\end{array}$ & 278 & $70 \%$ & 120 & $30 \%$ \\
\hline
\end{tabular}

In table 2, it is obvious that many resources are required by schools in order maintain and encourage good relationship with its communities. Item 1 shows that. $73 \%$ of the participants agreed that classrooms are required by school to achieve effective school community relationship. Classrooms can be allowed to be used by the community when school close or is on holiday. In item 2 , it is indicated that $54 \%$ of the respondents agreed that school library can be used to promote school community relationship. The school can provide in library books for parents to use. Item 3 indicates that $69 \%$ of the participants agreed that school halls can be used by the community for social events.

In table 2 under item 4, it is shown that $67 \%$ of the participants agreed that school play grounds can be used by the community for local games. Item 5 indicates that $59 \%$ of the participants disagreed with the statement that said school vehicles can be used for community services. In item 8 , it is indicated that $63 \%$ of the participants agreed that school parks can be used by community during festive seasons. In item 6 , it is indicated that $81 \%$ of the participants agreed that school business centres can provide services to the community. Item 7 shows that $70 \%$ of the participants agreed that school technical workshops can be used for community services.

\section{Summary of Findings}

1. School community relationship is very significant in the development secondary education in Zamfara State. Because it helps in the discipline of students, welfare of teachers, the planning of curriculum and information sharing and dissemination. It also helps in the provision of school facilities, finance, policies, security, management decision and in monitoring students' progress and lobbying benefits for school.

2. The resources which Zamfara State Senior Secondary Schools required for encouraging school community relationship are classrooms, halls and theatres, playgrounds, libraries, business centres, restaurants and/or canteens, furniture, parks and gardens and school farms.

\section{Discussions of Findings}

In table 1, results of the data presented showed that school community relationship is very important in promoting performance of Senior Secondary Schools in Zamfara State. It is worthy of note here that the important role which school community relationship plays in the administration of school made this research valuable. The findings in table 1 indicated that school community relationship helps in the discipline of students, helps in the welfare of teachers. This agreed with Fiore (2006) when he said by working 
together, schools, families and communities can furnish schools with crucial financial support system as well as the social and cultural values necessary for success such as welfare and discipline of teachers and students.

Another finding in table 1 showed that school community relationship helped in management decisions for smooth running of the school. When making decisions schools can seek the views of community members. This is necessary because whatever decision school makes will affect the community and its members directly or indirectly. Another important finding that demands community cooperation is the issue of monitoring students' progress. In terms of monitoring students' progress, community will be guided by the schools on how they can monitor their child progress and report what they observe about them.

In order for school to win the support of all the agencies, table 2 indicated there are that some resources which can be used to earn community support. The results in table 2 indicate that classrooms can be allowed to be used by the communities when school closes or is on holidays. This will help establish good relationship with the community. According to the findings in table 2, school library can equip a room with books that parents can come to read and borrow. The books to be provided should be of interest to the parents such as books on child psychology, married life, current affairs, health care, etc. The findings also suggested that community agencies can be allowed to use school halls, theatres and playgrounds for social events, meetings, games and festivals. This will make community agencies be concerned with whatever would be happening to the school. It is among the findings in table 2 that school parks and gardens, business centre and technical workshop are good resources which can be used to establish everlasting school relationship with communities. For example, school can establish business centres, and/or technical workshops around the gate of the school. This will be intended to serve both the school and the neighbouring community. This will always bring the school closer to the community members and they will be most concerned with anything that will affect the school. In respect to this, Kenkwo (1992) observes that the school depends on the community for a number of resources, such as water, land, human resources (skilled and unskilled labourers), accommodation for staff, finance and equipment for the continued existence of the school. On the other hand, the community depends on: the school for the provision of man power; the school halls for their meetings; the playground for their cultural activities; and the school buildings for emergency cases. In the same vein, Agabi and Okorie (2005) noted that the classrooms are used for adult literacy activities nationwide, for public activities like immunizations and public enlightenment exercises and in emergency epidemic situations, school buildings are converted into makeshift hospitals. Schools buildings are also put into use during voting exercises.

\section{Recommendations}

The following recommendations were made:

1. School principals should have some information about the 
community they serve. They should have information about the composition of the community such as the income, educational level and occupations of the majority of the residents. The principals should also know what community opinion is regarding both broad educational issues and day to day operation of the school itself. This will help them determine the major areas to be related to their communities.

2. School administrators should acquaint themselves with educational resources available in the community in order that they can be utilized to enrich and enhance the school programmes. Doing this could help school administrators identify and develop school resources that can be used to serve the community for better school community 'give and take' relationship.

\section{Conclusion}

In this research, it could be reasonably concluded that school community relationship plays very significant role in the development of secondary education in Zamfara State and that secondary schools resources must be used judicially to encourage this relationship. If secondary schools are to be developed in a positive direction, school community relationship must be taken very seriously.

\section{References}

Agabi, O. G,; Okorosaye-Orubite; Ezikiel-Hart, J. \& Egbezor. D. E.
(2005). School and society. Port Harcourt: Davidstone Publishers

Agabi, O. G. \& Okorie, N. C. (2002). Introduction to management of change in education: a book of reading. Port-Harcourt: Pam Unique Publishers.

Calhoun, C; Light, D. \& Keller, S. (1998). Understanding Sociology. New York: Glencoe/McGraw Hill

Fiore, D. J. (2006). School community relation (2nd ed.). Eye on education.Retrieved on February, 28, 2011, from http://books.google.ca/book?id.

Ihebereme, C. (2008). Factors militating against effective performance of principals in secondary schools in Nigeria. Joumal of Qualitative Educatio,.4 (1): 322-329.

Kenkwo, R. O. (1992). A study of school-community relationship in secondary schools in Etiti LGA. An M.Ed. Thesis, Faculty of Education, University of Port Harcourt.

Krejcie, R. \& Morgan, W. (1971).Determining sample size for research activities. Educational and Psychological Measurement, 30.

Madiewesi, E. J. (1991). The primary school. In. R. O. Ohuche (Ed.), Moving education in Nigeria toward the year 2000 grading of first, second, third congress in Nigeria academy education. Enugu: Optimal Computer Solution Ltd. 
Mishra, R. C. (2007). History of education administration. New Delhi: APH Publishing Corporation.

Musaazi, J. C. S. (1994). Maintenance and supervision of facilities and equipment for primary school: A paper presented at induct course organized by State Primary Education Board, Sokoto.

Nwankwo, J. I.; Nwokafor, J. N; Ogunsanwo, O. A. \&Ighalo, A. S. (1985).In J.I. Nwankwo (Ed), Educational administration and supervision. Ibadan: Heinemann Educational Books (Nig) Ltd.

Okorie, N. C.; Ememe, O. N. \&Egu, R. H. N. (2009) School-community relations in the development of secondary schools: A focus on Aba Educational Zone. African Journal of Education and Development Studies, 6 (1): 22-38.

Oyedeji, N. B. (1998). Management in education: Principles and practices. Lagos: AKAS Publishers.

Sidhu, K. S. (2007). School organization and administration. New Delhi: Sterling Publishers PVT, Ltd. 